\title{
THE COMPARATIVE ANALYSIS OF SYNTACTIC FEATURES BETWEEN INDONESIAN AND ENGLISH DENOMINAL VERBS
}

\author{
Danang Satria Nugraha
}

\author{
d.s.nugraha@usd.ac.id \\ Department of Language and Art Education, Sanata Dharma University \\ Yogyakarta, Indonesia
}

\begin{abstract}
This paper aims to compare the syntactic feature of Denominal Verb (DnV) of Indonesian and English. The syntactic feature defined as a presentation of transitivity (and valency) on the construction of derivated verbs. Based on the observatory method formulated by Sudaryanto (2015), the data taken from the usage of Bahasa Indonesia and English written forms. Based on the Contrastive Syntax approach designed by Hickey (2017), the result shows two comparative descriptions, namely the similarities and the differences in syntactic features. First, both languages demonstrate common (a) transitive features and (b) intransitive features. Second, the differences are found in (a) the Indonesian transitive feature, (b) the markers of transitivity of Indonesian and English, and (c) the grammatical relations of the English DnV. Further study needs to conduct the detailed analysis of the Indonesian and English DnV role in sentence construction.
\end{abstract}

Keywords: DnVs, Contrastive Syntax, Indonesian, English.

\section{INTRODUCTION}

The formation of derivational verbs in Indonesian and English tend to be at a productive level. This tendency is marked by the various forms of derivational verbs constructed by speakers of Indonesian and English. Through the derivation process, DnV (henceforth DnV) forms such as storytelling and pictured, consider examples (1) and (2), commonly used in communication. These habits, communicatively, one of which is triggered and based on the power of language speakers to express ideas according to the purpose of speech with their speech partners (Smirnova \& Shustova, 2017, p. 8). Meanwhile, from a syntactic point of view, the emergence of the $\mathrm{DnV}$ construction was identified as a manifestation of the verb valence system, "the expression of valency" (vanGelderen, 2011, p. 106). In this context, it was agreed that valence is a specific term in syntax, "valence as a syntactic notion" (Haspelmath \& MüllerBardey, 2001). In this study, the presence of DnV constructs in Indonesian and English was assumed due to syntactic features, namely the type of verb valence and verb transitivity. In connection with this assumption, van Gelderen (2011) said that "In the typological literature, there has long been an interest in valency and particular cross-linguistic differences in expressions of valency" (vanGelderen, 2011, p. 106). Thus, the realization of valence through grammatical units in various languages, "across languages in their morphosyntax and interpretation" (Coppock, 2019, p. 110), is an interesting linguistic phenomenon.

Furthermore, with the same derivation pattern, namely $\mathrm{N} \rightarrow \mathrm{V}$, Indonesian and English $\mathrm{DnV}$ tend to have similarities in aspects of the verb type valence. However, what about the translational and grammatical relations of $\mathrm{DnV}$ construction as a derivational verb in English? In previous studies, for example, by Nugraha (2017a \& 2017b), the syntactic features of Indonesian DnV have not been compared with other languages. Likewise in English, although comparative studies of $\mathrm{Bb}$ verbs have been carried out (Boroditsky, Ham, \& Ramscar, 
2002; Roikienè \& Narmontienè, 2008; AlShujairi, Muhammed, \& Almahammed, 2015), research explicitly examining the syntactic features of $\mathrm{DnV}$ construction between English and Indonesian, in contrast, have not been widely publicized. Therefore, based on the understanding that "contrastive linguistics is a special case of the linguistic typology" (Gast, 2012, p. 2), contrastive studies seem to be of significance.

Considering trends in previous studies, the main objective of this study is to complete the comparative analysis section of the verb Indonesian and English. The statement becomes essential if it is positioned in the two benefit bases as follows. First, this research is theoretically useful. This study implements contrastive syntactic theory with the results in the form of a comparative description and pattern of Indonesian and English DnV construction rules. In the context of comparing the phenomenon of Indonesian and English $\mathrm{DnV}$, it can be found that there is a match between the theory and the solution of the language problem analyzed. Crystal elucidates that:

"In Chomsky's view, therefore, the aim of linguistics is to go beyond the study of individual languages, to determine what the universal properties of language are" (Crystal, 1987, h. 84).

Secondly, this research is useful in practice. The presence of this research is an example of the application of contrastive syntactic theory in Indonesian linguistic research. Description of description and pattern of rules as a result of research can be used to enrich the syntax analysis treasures. Thus, descriptive research into Indonesian is increasingly varied and comprehensive.

As part of the typological linguistic point of view (Stroobant, 2014), this contrastive research only takes one focus, namely the syntactic features, the transfer system, from the DnV construction in Indonesian and English. The DnV construction in question is as presented in (1) and (2).

(1) Adiknya, si Bluluk, hanya dapat bercerita bahwa abangnya diajak seorang sopir colt berwarna merah yang ngebut ke arah Magelang.
(2) I pictured all the people I would rather be spending my time with, the friends I got with, the group I partied with.

Bercerita and pictured construction as $\mathrm{DnV}$ is used to transitivize. Even so, the two constructions have differences in their marking and grammatical relations. The aspects of similarities and differences in syntactic features are the main focus of this study.

With both theoretical and methodological considerations presented in the previous section, this research describes aspects of the similarities and differences in syntactic features of $\mathrm{DnV}$ construction in Indonesian and English explicitly. Overall, the methods, results, and discussion of this study are presented in sequence as follows.

\section{METHODS}

This research was carried out in three stages, namely (a) data collection, (b) data analysis, and (c) presentation of analysis results. In the first stage, data are in the form of sentences with constituents filling in the predicate $\mathrm{DnV}$ form collected from the Indonesian and English writings. Indonesian data is derived from various standard Indonesian in (a) lexical entry text from the Indonesian Dictionary (Fifth Edition, 2016). (b) the prose text written by Mangunwijaya (2012) entitled Rumah Bambu, and (c) the news text in kompas.com accessed during November 2019. Meanwhile, the English data source is (a) lexical text entry from Cambridge Advanced Learner's Dictionary 3rd Edition and modern English (Crystal, 2003) which refers to the standard British English (Swan, 2009), (b) the prose by Mayberry (2016) entitled Winning Plays and (b) news text on thejakartapost.com accessed during November 2019. Two parameters limit the use of both languages: (a) having standard or formal variations and (b) in written form. Data collection was carried out by written document-observation of Sudaryanto (2015). The collected data is reduced to determine valid data for analysis. The unit of analysis in this study is the DnV construction of Indonesian and English.

In the second stage, contrast analysis is carried out regarding the contrastive syntax framework (Hickey, 2017). The main focus of the analytical framework is to identify and 
compare lingual units that affect syntactic functions. Carston (1994) suggested that "syntax is taken to be the study of the combinatorial properties of words" (Carston, 1994, p. 4481). In the second step, the shared transitivity features are obtained by identifying markers in the DnV construction. The markers are affixes that result from the process of verb formation through the derivation of nouns. With this identification, we can determine the transitivity or valency types. The categorization stage follows this identification. The basis of categorization is intransitive (single-valency verb), transitive (two-valency verb), and dual transitive (trivalency verb). The analysis stage ends with identifying the differences between Indonesian and English DnV transitivity features and, therefore, the contrastive distinction is focused on the type of marker and the grammatical relation. Both stages are complemented by data triangulation through re-checking techniques.

In the third stage, the results of the analysis are presented in the descriptive analysis of the similarities and differences in syntactic features. Besides, this stage provides a summary table, patterns of verb formation rules, and examples of data. In addition to these three stages, forms of data testing are also displayed to clarify the description. To validate the results, some of the syntactician's assumptions and hypotheses are presented, along with the previously published research findings. The comparative study of $\mathrm{DnV}$ syntactic features of Indonesian and English was carried out based on these stages.

\section{RESULTS AND DISCUSSION}

In general, it can be stated that the syntactic features of DnVs (DnV) in Indonesian and English have similarities and differences. The equation lies in the transitive and intransitive characteristics in the construction of the two languages VD n. The difference lies in the transcriptional markers, dual transitive characteristics, and grammatical relations. Referring to Laks' assumptions, the findings are inseparable from the valence (is) changing operations (Laks, 2008). Hypothetically, changes in valence will have implications for changes in syntactic features. Next, a discussion of the similarities and differences between Indonesian and English $\mathrm{DnV}$ is presented as follows.

\section{Syntactic Features}

The standard syntactic features between the Indonesian and English DnV, in particular, is the presence of transitive and intransitive features. By both having SVO word order patterns (subject-verb-object) (Kamayani \& Purwarianti, 2011), DnV construction in Indonesian and English tend to have single valence and two valencies. The sequence pattern is a type of fixed word order, which is a grammatical feature of Indonesian and English. SVO sequence patterns in Indonesian and English cannot be exchanged as in the case grammar. The sentence I love you in Indonesian has the same structure as I love you in English, i.e., SVO. However, in Latin, which has a case-language style, the sequence pattern is not fixed word order, the sentence is sufficiently realized by the constituents of amo or the full version of ego amo te, amo ego te, or te ego amo. In previous studies, it was mentioned that as a derived verb, the construction of Indonesian DnV has a valence like a pure verb (Nugraha, 2017b). Does DnV construction in English also own the same characteristic? It should be remembered that "a predicate is commonly said to be transitive if it has two arguments and intransitive if it has only one" (Bowers, 2006, p. 183). In full, the syntactic feature equation is described in the following section.

\section{Transitive Feature}

Transitive traits are owned by several types of $\mathrm{DnV}$ constructs in Indonesian and English. In Indonesian, DnV is constructed by following the pattern [affix $+\mathrm{N}$ ? Vtransitive]. Meanwhile, in English, DnV is formed by following two patterns, namely (a) [affixerivatioanl $+\mathrm{N}$ ? Vtransitive] and (b) $[\{\varnothing\}$ $+\mathrm{N}$ à Vtransitive]. Pattern (b) is known as conversion or zero derivation (Crystal, 2003) or unmarked derivation (Mahdi, 2012, p. 403). As an additional note, in previous studies, there is a transmutation process that incorporates nouns, which can form the construction of English DnV, for example, to doctor, to sentence, to knife, to nest (Smirnova \& Shustova, 2017). The process is not the focus of this contrastive study because the DnV construction produced tends not to be 
positioned in the filler predicate function of a clause or sentence.

Indonesian DnV constructions can be identified as transitive verbs when filling in the predicate function. Although it is realized that "In Indonesian, the predicate can be verbal (and nonverbal)" (Sujatna, 2012, p. 135), the data found in this study show the same pattern, namely DnV construction has always been a predicate filler. In the position of the nonverbal predicate, that is, nouns fill in the predicate function, the feature of transitivity cannot be identified because the constituents are positioned as having no valence. Compare the sentences he went to Leiden University, and that was my old school. Both of these sentences both have the word SCHOOL as one of its constituents. However, the syntactic behavior of the two words is different, one as a derivative verb and the other as a predicate fill noun. Thus this distinction needs to be made when identifying the DnV construction characterized by transitive in sentence construction.

In detail, the DnV construction that has a transitive characteristic is characterized by several affixes, as presented in table 1 . Morphological changes in arising indicate changes in the valence of the verb construction (Haspelmath \& Müller-Bardey, 2001).

Table 1. Indonesian Transitive DnV Markers

\begin{tabular}{lll}
\hline \multicolumn{2}{c}{ Affix Types } & Example \\
\hline Prefix & $\{$ me $(\mathrm{N})-\}$ & Mengunci \\
\hline Confix & $\{$ ber-kan $\}$ & Bertahtakan \\
\hline Combinati & $\{$ me(N)-i $\}$ & Mewarnai \\
on & me(N)-kan $\}$ & Menggambarkan \\
& \{memper- $\}$ & Memperalat \\
& \{memper-kan $\}$ & Mempertanyakan \\
& \{memper-i $\}$ & Mempermantrai \\
& $?\{$ me $(\mathrm{N})-\}+\{\mathrm{R}\}$ & \\
\hline
\end{tabular}

Source: (Nugraha, 2017b)

As presented in Table 1, morphological marking is a trend in IB. By identifying the markers' presence, we can determine the transitive characteristics of a clause/sentence's predicate. See the sample excerpt (3) along with the discussion.

(3) Judul buku ini menggambarkan sosok Pak Anton yang dengan setia menaburkan benih-benih keilmuan di mana pun beliau berada. (3a) *Judul buku ini menggambar sosok Pak Anton yang dengan setia menaburkan benih-benih keilmuan di mana pun beliau berada.

The construction menggambarkan in the sample (3) is a DnV formed by combining noun Gambar and affixes $\{\mathrm{me}(\mathrm{N})-\mathrm{kan}\}$. If one part of the construction is neglected, for example, affix \{me (N) -kan\}, * The title of this book draws the figure of Mr. Anton ..., sentence construction becomes un-grammatical and unacceptable (has no intention) for speakers of Indonesian. If the affixes in the construction are replaced, for example, with me $(\mathrm{N})-\}$, sentences tend not to be grammatical. Check out the presentation (3a). Thus, the distribution of affixes and nouns as a unit in filling the predicate function is a characteristic of the Indonesian DnV. The transitive characteristic of the construction is also referred to as monotransitive (Asako, 2012, p. 61).

After examining the presentations (3) and (3a), compare them with the following presentations (3b) and (3c). Presentations (3b) and (3c) are used to show the noninterdependent nature of the transitive Indonesian DnV construction.

(3b) *Judul buku ini menggambari sosok Pak Anton yang dengan setia menaburkan benih-benih keilmuan di mana pun beliau berada.

(3c) *Judul buku ini mempergambar sosok Pak Anton yang dengan setia menaburkan benih-benih keilmuan di mana pun beliau berada.

The syntactic behavior of predicate fill constituents shown by (3b) and (3c) cannot be expressed as a grammatical function. The two presentations do not represent the meaning of the sentence as a unified meaning. The construction drawing in (3b) and drawing in (3c) are not DnV constructions. Substitution of marker affixes in sentences (3b) and (3c) cannot create a transitive DnV structure like in presentation (3). Thus, confirmation can be obtained from findings of the noninterchangeable nature of intransitive Indonesian DnV construction.

Meanwhile, in English, the construction of DnVs must go through a morphological process before it can fill the predicate function. 
Both patterns (a) and (b), as presented at the beginning, both must be distributed with inflectional affixes to carry out grammatical functions (tenses). For this reason, in order to fill the predicate function, the pattern is completed (a) [[affix derivational $\left.+\mathrm{N} \rightarrow \mathrm{V}_{\text {transitive }}\right]+$ affixinflectional $]$ and (b) $\left[\{\varnothing\}+\mathrm{N} \rightarrow \mathrm{V}_{\text {transitive }}\right]+$ affixinflectional]. The existence of grammatical functions imposed on the predicate in a clause may cause the construction of DnVs to be more complex in appearance than Indonesian DnVs. The denominals have undergone a process of transitivization (Stroobant, 2014, h. 5).

The construction of DnVs can be identified as transitive verbs when positioned to fill in the predicate function. Resembling the construction of the Indonesian DnV, affixes in the construction of BG can mark transitive characteristics. Based on some markers are presented in table 2 , it is found that $\{$-ate $\}$ tends to be constructed into transitive verbs. Take a look at the presentation (4) along with the discussion.

(4) I am just chlorinating my liquid. It should only take a few hours.

(4a) *I chlorine my liquid. It should only take a few hours.

(4b) ?I chlorinated my liquid, ...

The excerpt I am just chlorinating construction in presentation (4) has the chlorinate constituents, which are DnVs. These constituents are distributed along with inflectional affixes to become predicates in the construction of sentence (4), i.e. $\{$ be $\}+\{V$-ing $\}$. If part of the construction is obsolete, for example, it becomes (4a) * I chlorine my book ..., construction (4) becomes un-grammatical and unacceptable (has no intention) for English speakers. The construction built through zero $\{\varnothing\}$ derivation can be pictured, captured, booked, scheduled, and their likes. Both DnV constructions are formed by derivation and zero derivation, which can be positioned as fillers in the predicate. No different from the syntactic characteristics of Indonesian DnV, which have non-interdependent properties, English DnV transitive also cannot replace each other. The constituents forming the $\mathrm{DnV}$ construction, especially affixes of derivational, cannot be exchanged with other types of derivational affixes. DnV constructions in
English are recognized as morphosyntactic complexity (Gonzálvez-García, 2019, h. 124).

Table 2. Transitive Markers of DnVs

\begin{tabular}{lll}
\hline Affix Types & & Example \\
\hline Suffix & $\{$-ate $\}$ & Chlorinate \\
& $\{$-ify $\}$ & Beautify \\
& $\{$-en $\}$ & Darken \\
& $\{$-ize $\} /\{$-ise $\}$ & Criticize \\
\hline
\end{tabular}

Source: (Crystal, 2003)

Thus, the Indonesian and English DnVs have two valencies, which require the presence of the subject and the object's functions. These groups of verbs are known as monotransitive verbs (Asako, 2012, h. 61).

\section{Intransitive Features}

In addition to the two validity, DnVs in Indonesian and English can have the characteristic valence of one, which only requires the presence of the subject's function in its distribution as the predicate of a clause or sentence. In general, derivational verbs with one valence in Indonesian and English are translated into intransitive form. In Indonesian, the verb is constructed by following a pattern [affix $+\mathrm{N} \rightarrow \mathrm{V}_{\text {intransitive }}$. The pattern requires conformity between $\mathrm{DnV}$ predicate function fillers and other constituents filling subjects and predicates. Transitivity deals in distinguishing verbs according to whether they have an object or not (Emilia, Moecharam, \& Syifa, 2017, p. 209).

Table 3. Indonesian Intransitive DnV Markers

\begin{tabular}{lll}
\hline Affix Type & & Example \\
\hline Prefiks & $\{$ me $(\mathrm{N})-\}$ & Mengeong \\
& $\{$ ber- $\}$ & Berkemeja \\
& $\{$ ter- $\}$ & Terkunci \\
\hline Confix & $\{$ ber-an $\}$ & Bersahutan \\
Combinati & $\{$ ber-R $\}$ & Berlembar-lembar \\
on & & \\
& $\{$ ber-R-an $\}$ & Bersalam-salaman \\
\hline
\end{tabular}

Source: (Nugraha, 2017b)

Indonesian DnVs are identified as marked verbs. The marked verbs are always distributed together (affixed) by markers (Sugono, 2015). It is based on the affixes that affect the distribution of verbs when filling in the predicate function. In previous studies, the marker of Indonesian DnV was identified. Take a look at the presentation of table 3 and the form of construction (5) and their discussion. 
(5) Banyak pendekatan tradisional terhadap bahasa berasumsi bahwa unsur struktur bahasa secara sistematik dapat dikodekan.

(5a) *Banyak pendekatan tradisional terhadap bahasa asumsi bahwa unsur struktur bahasa secara sistematik dapat dikodekan.

The construction berasumsi is an intransitive DnV that fills in the predicate function in the sentence (5). If the affixes in the verb are disfigured as in (5a), *banyak pendekatan tradisional terhadap bahasa asumsi bahwa..., the sentence becomes not grammatical.

Meanwhile, in English, the construction of DnVs characterized by intransitive forms can be manifested, for example, apologize, criticize, and darken. Derivative affixes that tend to mark intransitive traits are $\{$-ize $\} /\{-$ ise $\}$ and \{-en\}. Take a look at excerpt (6) along with the discussion.

(6) Governor apologizes on behalf of East Java after racial abuse hurts Papuans.

(6a) *Governor apology on behalf of East Java after racial abuse hurts Papuans.

The constituent apologizes in (6) is DnV that fills in the predicate in the sentence. Verb apologizes fills in the predicate function when distributed with affix $\{-s\}$, formed from apology nouns and affixes $\{$-ize $\}$. If the types of affixes are disregarded, the presentation (6) will become (6a), * Governor apology on behalf ..., which is not grammatical and difficult to understand in terms of its construction. The presence of these affixes is the key to the process of transitivization what is known as the "transitivising functions of verbal morphemes" (Kulikov, 2012, h. 721).

\section{Differences in the Syntactic Features}

Specifically, the differences in syntactic features between Indonesian and English DnVs include a) Indonesian DnV construction has multiple transitive features, b) Indonesian DnV translational markers tend to be more diverse than English DnV markers, and c) grammatical relations of English DnVs are more diverse than Indonesian's. The difference features come from the different valence patterns between Indonesian DnV and English DnV. It should be noted that "the configuration of arguments that are governed by a particular lexical item is valence pattern" (Haspelmath \& Müller-Bardey, 2001). A discussion of these different features in full is presented in the following sections.

\section{Ditransitive Features}

The ditransitive feature is easily found in Indonesian DnV construction, but it is difficult to find in the construction of English DnV. Based on the analysis, DnV construction is likely to be distributed in transitive and intransitive characteristics. Unlike this tendency, the construction of Indonesian DnV has various transitivity forms, ranging from intransitive, transitive, and ditransitive (Asako, 2012, p. 61). The different syntactic behavior is the crucial difference between Indonesian and English DnV. Basically, "a verb's valency is how many arguments it can bind" (Bozzone, 2015, p. 4). In full, the following discussion presents a description of the Indonesian ditransitive $\mathrm{DnV}$ marker along with the description. Information about the markers of Indonesian $\mathrm{DnV}$ construction is presented in table 4 .

Tabel 4. Indonesian Ditransitive DnV Markers

\begin{tabular}{ll}
\hline Affix Type & Example \\
\hline Combinati $\quad$ (me(N)-kan) & Memahatkan \\
on & \\
\hline Source: (Nugraha, 2017b) &
\end{tabular}

The pattern of the formation of Indonesian $\mathrm{DnV}$ construction with a transitive feature is $\mathrm{N}+\{$ me $(\mathrm{N})-\mathrm{kan}\} \rightarrow \mathrm{V}_{\text {ditransitive. Look }}$ at sample excerpt (7) and its discussion.

(7) Bli Made memahatkan Ibu sebuah relief.

(7a) Ibu dipahatkan bli Made sebuah relief.

(7b) *Bli Made pahat Ibu sebuah relief.

(7c) ?Bli Made memahat bu sebuah relief.

In presentations (7) and (7a), the carved and carved constituents are dual transitive DnV. Carving construction fills in the predicate function in the sentence (7). The presence of DnV carving requires the distribution of three arguments, namely in the position of the subject, direct object, and indirect object. If the transliteration markers in the memahatkan construction are shown in (7b), the sentence 
becomes ungrammatical or unacceptable. Meanwhile, if a marker is replaced, for example, by me $(\mathrm{N})-\}$, check the presentation (7d), the transitive feature changes to transitive.

The relation between the markers and the characteristics of the transmission is on an equal level. That is, the change in affix marks the change in the valence of the DnV construction. These characteristics tend not to be found in DnV construction. Although the number of variations in Indonesian doubletransitive DnV construction is not many, the existence of these characteristics can be positioned as a distinctive feature of other languages. It can be said that morphosyntactically, the derivational affixes play a crucial role in the transitivization of Indonesian ditransitive DnV.

\section{Transitive Markers}

Based on the analysis, it can be stated that the number of Indonesian DnV transitive markers is more diverse than the English DnV markers. This difference has two implications. First, the process of forming DnVs in Indonesian is more varied than English. "In English, suffixes do more than alter the meaning of the word to which they are attached; many of them change the grammatical status, i.e., \{-ate\}, \{-en\}, \{-ify\}, and \{-ize/-ise\}" (Crystal, 2003, p. 128 \& 198). Meanwhile, in Indonesian, approximately fifteen affixes are forming $\mathrm{DnV}$ construction (check tables 1, 3, and 4). The comparison of the number of affixes is indeed not significant. It means that with a limited number of affixes, several grammatical functions can be generated. Conversely, with a large number of affixes, only a few grammatical functions can be created. See the description (8) below.

(8) Acting regent's son criticized for 'unfail' participation in flag-hoisting team.

(8a) *Acting regent's son critic for 'unfail' participation in flag-hoisting team.

(8b) *Acting regent's son criticize for 'unfail' participation in flag-hoisting team.

(8c) *Acting regent's son criticizing for 'unfail' participation in flag-hoisting team.
The criticized construction is a DnV that fills the predicate function in (8). To be able to fill that function, inflectional affixes $\{$-ed $\}$ are distributed along with criticize construction formed from critic and \{-ize\}. If the markers are missed, check (8a), the sentence is not grammatical. Servings (8b) and (8c) are not grammatical because tense functions are not affected by the presence of an affix. Because of these markers' presence in a long sentence, the DnV construction that fills in the predicate has a more complex function than Indonesian DnV. These characteristics are identified as complextransitive argument structures (Hampe, 2011, p. 211). The pattern created is $\left[\mathrm{N}_{\text {roots }}+\right.$ affix $\rightarrow$ $\mathrm{V}_{\text {derivational }}(+\mathrm{affix}) \rightarrow \mathrm{V}_{\text {inflectional]. Also, see the }}$ sample (9) along with the following description.

(9) This painting perfectly exemplifies the naturalistic style which was so popular at the time.

(9a) *This painting perfectly example the naturalistic style which was so popular at the time.

(9b) *This painting perfectly exampling the naturalistic style which was so popular at the time.

The exemplifies construction is a $\mathrm{DnV}$ that fills in the predicate function in the presentation (9). In order to fill that function, inflectional affixes (-s) are distributed along with the exemplify construction. Exemplify constructs are formed from example and \{-ify\}. If the markers are missed, check the presentation (9a), the sentence is not grammatical. Likewise, when the inflectional affix replacement procedure is applied as in (9b), the sentence becomes non-grammatical. Based on the sample presentations (8) and (9), it can be stated that the DnV is still signified by derivational and inflectional affixes representing the type of transmission in the sentence structure.

Compare the descriptions (8) and (9) with the Indonesian DnV forms in table 5 and the sentence discussion (10). It can be said that morphosyntactically, the number of transitive derivational markers in Indonesian is more significant than in English. When traced, the amount of Indonesian derivational affixes can still be added to dialectal affixes such as $\{\mathrm{N}-\}$ and $\{$-in\}. So far, this finding has been 
motivated by facts about the grammatical characteristics of Indonesian. Syntactically, Indonesian is known as a language with a vital affix system or has a primary function in the construction of verbs that fill in the predicate function in sentences. Although it is realized that the affixes of Indonesian do not carry the flexion function of the time, the flexion of the number of singular/plural as in the $\mathrm{DnV}$ construction, variations in the variety of Indonesian affixes can create a pattern of formation of diverse Indonesian DnV transmittance. Thus, it can be stated that the process of the formation of Indonesian $\mathrm{DnV}$ is more varied than the formation of English DnV.

Second, Indonesian DnV constructions tend to create diverse types of transport. Various meanings can be in the form of transitive, dual transitive, and intransitive. This tendency is affected by construction affixes. Look again at the presentations (7) and (7c). With affix replacement, two different types of transport are obtained. This combination of changes can occur productively in Indonesian. With approximately fifteen derivative affixes of DnV construction markers, the types of transport created can vary. This particularity is not found in the construction of English DnV. With more or less four types of affixes, the transitivity created tends to be transitive and intransitive. In addition, there was a tendency for three affixes that were genuinely distributed productively in the formation of DnV constructs, namely \{-ize $\}$ / $\{-$ ise $\},\{$-ate $\}$, and $\{$-en\}. Affix $\{$-ify $\}$ tends to be unproductive. Of the four types of affixes, $\{$-ize $\}$ / $\{$-ise $\}$ can be found commonly in the construction of $\mathrm{DnV}$ on various forms of English writing. Mair's view stated, "That is, derivation by means of suffixing, rather than prefixing" (Mair, 2013, p. 65).

Tabel 5. Variasi Wujud DnV berkonstituen CERITA

\begin{tabular}{ll}
\hline Affix Type & Example \\
\hline$\{$ me(N)-kan $\}$ & Menceritakan \\
\hline$\{$ ber- $\}$ & Bercerita \\
\hline$\{$ me $(\mathrm{N})-\mathrm{i}\}$ & Menceritai \\
\hline
\end{tabular}

Next, compare with the Indonesian DnV markers in the presentation of tables 1,3 , and 4 and consider the following description of the data sample (10).
(10) Ibu sedang asyik menceritakan pendidikan anak-anaknya.

(10a) *Ibu sedang asyik cerita pendidikan anak-anaknya.

(10b) *Ibu sedang menceritai pendidikan anak-anaknya.

(10c) ?Ibu sedang bercerita pendidikan anak-anaknya.

The presentation (10) presents the DnV narrative construction that marks the sentence's transitivity structure. As a filler in the predicate, the story's construction is accompanied by two other constituent parts, namely, the first valence in the form of a maternal constitution and the second valence in the form of children's education. Because of this pattern of transitivity, presentation (10) can be classified into transitive sentences. The sentence is not grammatical if it is subjected to a seduction process. Check the presentation (10a). Decrease \{mem (N) right $\}$ as a marker of DnV implies that the predicate function is not realized in the sentence (10). Marking with derivational affixes is a sign of a syntactic function imposed on nouns whose word class is converted into verbs. If examined further, sentence (10) which is subjected to a substitution process, also shows the same nongrammatical behavior. Pay attention to sentence (10b). Derivative affix substitution implies a change in the transitivity system. Sentences with story construction have the potential to create sentences with three valences (in the position of the subject, direct object, and indirect object). In sentence (10b), this potential cannot be achieved. Changes in sentence valence also occur when substitution is treated as in sentence (10c). With story construction, sentence (10c) only requires the presence of one argument that becomes valence, namely the maternal constituents as fillers of the subject's functions.

The following pattern of rules is obtained from the description that has been explained in the previous paragraph. Indonesian DnV constructions tend to create diverse types of transport. The noun STORY (a) can be transitive when derivated from menceritakan, (b) can be intransitive when derivated from bercerita, and (c) can be transformed when derivated from menceritai. The potential quality of the formation of transitive structure 
is not likely to be found in English DnV construction.

\section{Grammatical Relations}

The grammatical relation features are limited to the construction of $\mathrm{DnV}$ as a predicate of clauses or sentences. In inflectional languages, such as English, these features are the main differentiator of Indonesian. The presence of DnV construction as a predicate clause or sentence is loaded with inflection features when, plural or non-plural, and other aspects of tenses. This particularity is not found in the construction of Indonesian DnV. "Indonesian is essentially an accusative language" (Aldridge, 2008, p. 1448). Meanwhile, English tends to be an inflectional language. If it is patterned, the specific rule of DnV can be realized in figure (1).

$\left[\mathrm{N}_{\text {rools }}+\right.$ affix $\rightarrow V_{\text {derivational }}(+$ affix $) \rightarrow V_{\text {inflectional }}(+$ affix $\left.)\right]$

Figure 1 Pattern of Nominal Change in English DnV

The complexity of the relationship shown in figure (1) is not found in Indonesian DnV. Check the Indonesian DnV pattern in figure (2). Thus it can be stated that the English DnV construction has broader grammatical relations than the Indonesian DnV construction. Although both fill the predicate function, the construction of $\mathrm{DnV}$ is subject to varying relations. "The verbal properties of transitive agent nouns are due to a Tense / Aspect feature assigned to these nouns by the affix agent that forms them" (Bowern, Horn, \& Zanuttini, 2017, p. 315).

$$
\left[\mathrm{N}_{\text {roots }}+\text { affix } \rightarrow \mathrm{V}_{\text {derivational }}\right]
$$

Figure 2 Patterns of Nominal Change in Indonesian DnV

Furthermore, constructions built based on the drawing pattern (1) can be found in example (11). Check the presentation (11) along with the discussion.

(11) The sky darken as thick smoke Indonesian llowed from the blazing oil well.

(11a) *The sky dark as thick smoke Indonesian llowed from the blazing oil well. (11b) *The sky darking as thick smoke Indonesian llowed from the blazing oil well.

Presentation (11) was built using the darken DnV construction as a predicate filler. The presence of darken in the construction is accompanied by several grammatical relations, namely single flexion, single flexion (present), and tense (simple tense) flexion. Items (11a) and (11b) that are subject to affixation and replacement of affixes are identified as nongrammatical construction.

Also check out the presentation (12) along with the description as follows.

(12) Biologist classify animals and plants into different groups.

(12a) *Biologist class animals and plants into different groups.

(12b) *Biologist classing animals and plants into different groups.

The presentation (12) was built using classify construction as predicate fill constituents in the sentence. The presence of classify in the construction of the sentence is accompanied by several grammatical relations, namely plural flexion (plural), flexion when (present), and flexion type tense (simple tense). The grammatical relation cannot be formed if it is subject to the impregnation and replacement of the $\mathrm{DnV}$ construction elements. If affix $\{-i f y\}$ is treated as in (12a), sentence (12) loses the predicate function. sentence (12) is ungrammatical and unacceptable because it does not have a transitivity structure that has implications for the not forming of grammatical meaning. Likewise, when the substitution process applies to sentence (12), for example by substituting \{-ing\} in that sentence. The presentation (12b) is an ungrammatical form. There is no meaning of the sentence formed because the structure of transitivity is not realized by the verbs in the sentence.

Taking into account the presentations (11) and (12), it can be stated that the rules that are raised are without the distribution between DnV and inflectional affixes as predicate fillers, transitivity cannot be realized, the resulting DnV construction can be identified as complex predicate (CP) (Korn, 2013, p. 32). Meanwhile, it should also be noted 
that "In most syntactic approaches DnVs are formed by the incorporation of the bare nominals or roots into heads selecting them" (McIntyre, 2016, p. 9). The incorporation and derivation of nouns into verb categories is a form of changing lexical categories to achieve more vital syntactical functions, namely as predicates of sentences. From these findings, it can be stated that the marking of DnV construction is the source of the realization of transport. In other words, transitive, intransitive or dual transitive claims for DnV can only be made if the derivational and inflectional markers have been identified in the construction being entered.

In both presentations, the grammatical relations of DnV are nullified. These relations are not owned by Indonesian. "Indonesian is a configurational language without casemarking" (Musgrave, 2001, p. 31). Compare this with (13) which presents the Indonesian DnV construction.

(13) Awan menghitam di angkasa.

(13a) Awan hitam di angkasa.

(13b) *Awan berhitam di angkasa.

(13c) *Awan dihitam di angkasa.

The sample (13) was built using menghitam DnV construction as predicate fill constituents. The presence of these constituents is not accompanied by additional grammatical relations in addition to their status as intransitive predicate. Grammatical relations can be changed if subjected to sedimentation treatment as in data (13a) and marker replacement as in data (13b) and (13c) which are ungrammatical.

Also check out the presentation (14) along with the following discussion.

(14) Sudah lama, ia tidak menyurati keluarganya.

(14a) *Sudah lama, ia tidak surat keluarganya.

(14b) ?Sudah lama ia tidak bersurat keluarganya

Not far from the blackened DnV construction, the writing construction is an embodiment of Indonesian DnV which is not accompanied by flective relations as in Indonesian DnV. The presence of the two DnV constructions is purely a manifestation of the structure of the transmission of the sentence Indonesian Sentence (13) marks the intransitive structure and sentence (14) marks the transitive structure. In particular, sentence (14) becomes non-grammatical if subject to impregnation and substitution. In presentation (14a) it can be seen that without the presence of derivational affixes, letter construction does not carry the syntactic function of the predicate. In context (14a), the structure of the transmission cannot be formed if the basic noun fills in the predicate function. Nevertheless, grammatical potential can be formed if substitution with other affixes, namely $\{B E R\}$ as presented in (14b) sudah lama ia tidak bersurat (dengan) keluarganya.

The comparison between the pairs (11) and (12) and pairs (13) and (14) demonstrate that as a filler the predicate of English DnV construction has a more complex relation than Indonesian DnV. This comparison is also found in the comparative study of the transitivity between English and Arabic. English verbs tend to have more diverse grammatical functions by applying inflections (Al-Shujairi et al., 2015). Thus, it can be stated that the distinctive features between Indonesian and English DnV tend to be caused by different valence patterns. These differences lead to differences in morphological forms and syntactic relations.

\section{CONCLUSION}

The construction of DnVs in Indonesian and English has similarities and differences in syntactic features. Based on the aspect of transitivity, both Indonesian and English DnVs have transitive and intransitive characteristics. Meanwhile, the difference in both languages' DnVs lies in the two-transitive features, variations in transactional markers, and grammatical relations. Thus, it can be stated that syntactically Indonesian and English DnVs have similarities and differences. Specifically, these similarities and differences stem from different valence patterns in them. For further research, the roles of Indonesian and English DnVs can be compared. It can complement contrastive descriptions of DnV construction in Indonesian and English. Besides, there is a tendency for phenomena that have not been analyzed and described in this study, namely the presence of dialectal affixes of Indonesian that can derive nouns into verbs. The dialectal affixes are like $\{\mathrm{N}-\}$ in the mbakso and nyate 
and $\{$-in\} in garamin and cabein. Presumably with a complete description can be found the emergence of new affixes Indonesian that can derive nouns. In a broader scope, future studies may compare the construction of deadjectival (DA) verbs, deverbal (DV) verbs, and denominal (DN) verbs. Based on a contrastive syntactic approach, descriptive research on these topics is worth conducting.

\section{REFERENCES}

Aldridge, E. (2008). Phase-based account of extraction in Indonesian. Lingua, 118(10), 1440-1469. https://doi.org/10.1016/j.lingua.2007.08.006

Al-Shujairi, Y. B. J., Muhammed, A., \& Almahammed, Y. S. O. (2015). Transitivity and Intransitivity in English and AraIndonesian c: A Comparative Study. International Journal of Linguistics, 7(6), 38. https://doi.org/10.5296/ijl.v7i6.8744

Asako, S. (2012). Applicatives in Standard Indonesian. Retrieved from https://doi.org/10.15021/00002529

Boroditsky, L., Ham, W., \& Ramscar, M. (2002). What is Universal in Event Perception? Comparing English \& Indonesian Speakers. Proceedings of the Annual Meeting of the Cognitive Science Society, 24(24), 7.

Bowern, C., Horn, L. R., \& Zanuttini, R. (Eds.). (2017). On looking into words (and beyond): Structures, relations, analyses. Berlin: Language Science Press.

Bowers, J. (2006). Transitivity. Linguistic Inquiry, 33(2), 183-224. https://doi.org/doi.org/10.1162/002438902317406696

Bozzone, C. (2015). Causatives that do not Cause,. UCLA, 1-22.

Carston, R. (1994). Syntax and Pragmatics. In The Encyclopedia of Language and Linguistics (Vol. 8, pp. 4481-4487). Great Britain: Pergamon Press Ltd.

Coppock, E. (2019). Quantity Superlatives in Germanic, or "Life on the Fault Time Between Adjective and Determiner". Journal of Germanic Linguistics 31(2), 109-200. https://doi.org/10.1017/S1470542718000089

Crystal, D. (1987). The Cambridge Encyclopedia of Language. Cambridge: Cambridge University Press.

Crystal, D. (2003). The Cambridge Encyclopedia of The English Language 2nd Edition. United Kingdom: The Press Syndicate of The University of Cambridge.

Emilia, E., Moecharam, N. Y., \& Syifa, I. L. (2017). GENDER IN EFL CLASSROOM: TRANSITIVITY ANALYSIS IN ENGLISH TEXTBOOK FOR INDONESIAN STUDENTS. Indonesian Journal of Applied Linguistics, 7(1), 206. https://doi.org/10.17509/ijal.v7i1.6877

Gast, V. (2012). Contrastive Linguistics: Theories and Methods. Retrieved from https://www.researchgate.net/publication/265070904

Gonzálvez-García, F. (2019). Exploring the pedagogical potential of vertical and horizontal relations in the constructicon:The case of the family of subjective-transitive constructions with decir 
in Spanish. International Review of Applied Linguistics in Language Teaching, 57(1), 121-145. https://doi.org/10.1515/iral-2018-2009

Hampe, B. (2011). Discovering constructions by means of collostruction analysis: The English Denominal Construction. Cognitive Linguistics, 22(2). https://doi.org/10.1515/cogl.2011.009

Haspelmath, M., \& Müller-Bardey, T. (2001). Valence Change. In G. Booi \& C. Lehmann (Series Ed.), A Handbook on Inflection and Word Formation (pp. 1-23). HSK-Morphology.

Hickey, R. (2017). Contrastive Linguistics. Institute for Anglophone Studies University of Duisburg and Essen.

Kamayani, M., \& Purwarianti, A. (2011). Dependency parsing for Indonesian. Proceedings of the 2011 International Conference on Electrical Engineering and Informatics, 1-5. https://doi.org/10.1109/ICEEI.2011.6021552

Korn, A. (2013). Looking for the middle way: Voice and transitivity in complex predicates in Iranian. Lingua, 135, 30-55. https://doi.org/10.1016/j.lingua.2013.07.015

Kulikov, L. (2012). Vedic preverbs as markers of valency-changing derivations: Transitivity and objecthood in Indo-European (Evidence from Old Indo-Aryan). Studies in Language, 36(4), 721-746. https://doi.org/10.1075/sl.36.4.01kul

Laks, L. (2008). Valence changing operations: Where does morpho-phonology interfere? Proceedings of ConSOLE XVI, 103-115. Retrieved from http://www.sole.leidenuniv.nl

Mahdi, W. (2012). Distinguishing Cognate Homonyms in Indonesian. Oceanic Linguistics, 51(2), 402449.

Mangunwijaya, Y.B. (2012). Rumah Bambu: Kumpulan Cerpen. Jakarta: KPG (Kepustakaan Populer Gramedia).

Mayberry, M. (2016). Winning Plays. New York: Center Street.

Mair, E. L. (2013). Why a Single Burst or Multiple Scatterings Can Make All the Difference: The Patterns Underlying the Formation of AI and AII Verbs. Studia Celtica Fennica, X, 65-80.

McIntyre, A. (2016). DnVs: An overview. In Word-formation: An International Handbook of the Languages of Europe (Vol. 4). Berlin: De Gruyter Mouton.

Musgrave, S. (2001). Non-subject Arguments in Indonesian. Department of Linguistics and Applied Linguistics The University of Melbourne.

Nugraha, A. D. S. (2017a). AFIKS-AFIKS DERIVASIONAL DAN TIPE-TIPE NOMINA DALAM KONSTRUKSI VERBA DENOMINATIF BAHASA INDONESIA. Bahasa dan Seni: Jurnal Bahasa, Sastra, Seni dan Pengajarannya, 45(1), 013-026. https://doi.org/10.17977/um015v45i12017p013

Nugraha, A. D. S. (2017b). KETRANSITIFAN VERBA DENOMINATIF DALAM KONSTRUKSI KALIMAT BAHASA INDONESIA. Jurnal Ilmiah Kebudayaan SINTESIS, 11(2), 78-86.

Roikienė, D., \& Narmontienė, K. (2008). DNVS IN TRANSLATION FROM ENGLISH INTO LITHUANIAN. 6. 
Smirnova, E., \& Shustova, S. (2017). Noun-incorporation in English as a valency-changing device. Lingua, 194, 15-25. https://doi.org/10.1016/j.lingua.2017.05.005

Stroobant, J. (2014). Factors triggering P-laIndonesian lity. GHENT UNIVERSITY - FACULTY OF ARTS AND PHILOSOPHY.

Sudaryanto. (2015). Metode dan Aneka Teknik Analisis Bahasa: Pengantar Penelitian Wahana Kebudayaan secara Linguistis. Sanata Dharma University Press.

Sugono, D. (2015). Tata Bahasa Dasar Bahasa Indonesia. Bandung: PT Remaja Rosdakarya.

Sujatna, E. T. S. (2012). Applying Systemic Functional Linguistics to Bahasa Indonesia Clauses. International Journal of Linguistics, 4(2), pp.134-146. https://doi.org/10.5296/ijl.v4i2.1506

Swan, M. (2009). English in the Present Day. In Concise Encyclopedia of Language of the World. Oxford: Elsevier.

vanGelderen, E. (2011). Valency changes in the history of English. Journal of Historical Linguistics, 1(1), 106-143. https://doi.org/10.1075/jhl.1.1.05van 
LiNGUA Vol. 15, No. 1, June 2020 • ISSN 1693-4725 • e-ISSN 2442-3823 